\title{
DOCUMENTS RELATING TO THE FORUM FOR REALIZING THE TRUE SOVEREIGNTY OF THE PEOPLE
}

In the months leading up to the 1992 Indonesian general election, a number of organizations arose in Indonesia with the aim of democratizing the electoral process for the Legislative Assembly. This Assembly is the body that under the 1945 Constitution will next year elect Indonesia's President and Vice President. Since the beginning of the New Order, this selection has been no more than a pro forma activity, but, in view of the fact that if President Soeharto is re-elected next year his sixth term of office will not expire until he is 76 years of age, his Vice President is much more likely than in previously terms to be called on to assume the presidential mantle. There has thus been a reasonable argument that this time the elections should be more than merely a "celebration of democracy," but should have more substance and greater input from political and social groups in Indonesia. One organization formed to articulate these demands has been the Forum Permurnian Kedaulatan Rakyat (FPKR - Policy for the Perfection of People's Sovereignty, or, as translated here, "Forum for Realizing True Sovereignty of the People" [F.R.T.S.P.]), headed by Retired Lt. General H. R. Dharsono, together with Dr.Deliar Noer and Abdul Madjid. In response to the policy of openness (terbukaan) espoused by the Soeharto administration in recent years, the Forum has also tried to initiate discussion of substantive policy issues and, in particular, to prod the present Legislative Assembly to assume a more active role in the political process.

The following documents chart the history of this Forum from its establishment in August 1991 to its decision on May 2, 1992 not to participate in the 1992 General Election.

\section{Document 1}

\section{DECLARATION}

ESTABLISHING

THE FORUM FOR REALIZING TRUE SOVEREIGNTY OF THE PEOPLE 1

\section{WITH THE MERCY OF THE ONE GOD ALMIGHTY}

Based on paragraph 28 of the 1945 Constitution guaranteeing the freedom to organize and assemble, as well as the freedom to express one's opinions and thoughts in oral, written or any other form

this conference, held on the 22nd of August 1991 in Jakarta and attended by 70 people, has

${ }^{1}$ Forum Pemurnian Kedaulatan Rakyat (F.P.K.R.). 


\section{IN UNANIMOUS AGREEMENT \\ RESOLVED \\ TO ESTABLISH}

THE FORUM FOR REALIZING TRUE SOVEREIGNTY OF THE PEOPLE

founded upon the principles expressed in the supplement accompanying and not to be separated from this Declaration.

May God Almighty bestow his mercy upon us

Jakarta, 22 August 1991

On behalf of the Conference,
A. Madjid
Deliar Noer
H. R. Dharsono

Supplement to the Declaration Establishing the Forum for Realizing True Sovereignty of the People

\section{FOUNDING PRINCIPLES \\ FORUM FOR REALIZING TRUE SOVEREIGNTY OF THE PEOPLE}

BASIS

We have founded the Forum for Realizing True Sovereignty of the People based directly on paragraph 28 of the 1945 Constitution guaranteeing freedom to organize and assemble as well as freedom to express opinions and thoughts in oral, written and any other form, on Pancasila, and on the Constitution of 1945.

FOUNDING PRINCIPLES OF THE F.R.T.S.P.

F.R.T.S.P. is an organizing forum by and for citizens of the Republic of Indonesia who believe:

-that the principles and practice of Sovereignty of the People at present have fallen far short of fulfilling the real ideals mandated by Pancasila and the Constitution of 1945, and

-that it is now time to pursue, through expression of public opinion and through constitutional action, a process of renewal aimed at purging our country of these failures.

FUNCTION OF THE F.R.T.S.P.

In the F.R.T.S.P., numerous opinions, thoughts, and convictions have been brought together to form a unified consensus that shapes both our basic concepts and constitutional actions aimed at establishing a state of True Sovereignty of the People in Indonesia.

F.R.T.S.P. will function as a mediating forum for addressing and assessing problems being faced by the People, for giving voice to the People's aspirations, and for struggling on their behalf by constitutional means.

SCOPE OF OUR STRUGGLE

The scope of F.R.T.S.P.'s struggle will cover the whole of our Homeland, as well as the concerns and everyday life of our People, Citizens, and Country.

LOCATION

F.R.T.S.P. will be based in Jakarta 


\section{STEERING COMMITTEE}

To ensure order and discipline in the Forum, a Forum Committee has been established whose form and function will match local conditions and current needs.

Jakarta, 22 August 1991

A. Madjid Deliar Noer

H. R. Dharsono

\section{PRESS RELEASE}

On this day, Thursday, 22 August 1991, the Forum for Realizing True Sovereignty of the People has been founded. Considered in light of the mandates of the 1945 Constitution, the founding of this Forum comprises a pursuit of the constitutional ideal of "sharpening the minds of the citizenry." Considered in light of recent events, this Forum comprises a response to the aspirations being expressed by the people.

In a general sense, the "Forum for Realizing True Sovereignty of the People" will try to put into practice a democratic way of life that, in addition to respecting universal values, also fundamentally upholds open dialogue as a means for guaranteeing human manifestations of the diversity of the nation [pengejawantahan yang manusiawi atas kebhinekkaan bangsa]. In other words, F.R.T.S.P. will work to put democracy into real practice in accordance with the ideals of our independence struggle. It is the Forum's conviction that this can only be pursued within an atmosphere of revival in the political, economic, and cultural spheres of life in our country. This and other issues are discussed more fully in the attachment accompanying this press release.

We hope the press will be willing to bring our message to the community, and thus make its own contribution to our collective efforts at democratizing the life of our country and citizens.

Jakarta, 22 August 1991
A. Madjid
Deliar Noer

H. R. Dharsono

\section{PRESS RELEASE}

It appears that the founding of the Forum for Realizing the Sovereignty of the People has already elicited comments from a number of sources, including some from among the ranks of the civil service. For the most part, these comments have been positive, though there have also been one or two instances where hesitation has been expressed. Despite the latter, the F.R.T.S.P. is grateful to the community for its comments and feedback.

As was highlighted in the declaration announcing its founding, F.R.T.S.P. has noted that there is much to be improved in the process of putting Pancasila and the 1945 Constitution into real practice. Much remains to be improved in the application of the sovereignty of the people.

Even though sovereignty of the people is officially recognized, in practice it is still not being realized in the way intended by the founders of the Indonesian Republic. A large part of the People's Advisory Assembly are still essentially assigned to their posts, even though paragraph 2, line 1, of the 1945 Constitution specifies that they should be elected.

General elections are considered to be a means to guarantee democracy, yet, as many people have recognized, the way in which these elections are conducted must still be improved (in order to ensure that they proceed directly, openly, freely, honestly, fairly, and according to secret ballot.) This issue is closely connected with five laws that regulate the political structure of this country. In the area of 
economics, we also find a number of obstacles preventing the true and systematic implementation of paragraph 33 of the 1945 Constitution.

F.R.T.S.P. will undertake all its actions in accordance with the constitution. As such, it very clearly does not intend to disrupt the general stability and order in the country. For this reason too, F.R.T.S.P. invites the people and wider community to examine with pureness of heart and clearness of thought the problems we are facing, in order that we may all work together to improve the condition of our country.

May this information have served to provide further clarification on the F.R.T.S.P.

Jakarta, 30 August 1991

H. R. Dharsono

Lieutenant-General of the Indonesian Armed

Forces (Retd.)

\section{Document 2}

MAIN POINTS

for

REALIZING TRUE SOVEREIGNTY OF THE PEOPLE

WITH THE MERCY OF ALMIGHTY GOD MOST JUST

After discussing all opinions, suggestions, proposals, and recommendations, the conference on the Forum for Realizing True Sovereignty of the People which took place on 22 August 1991, has agreed on the following MAIN POINTS for REALIZING TRUE SOVEREIGNTY OF THE PEOPLE:

\section{Politics}

While maintaining a belief in God and rule by the people, democratization must be based on a deep appreciation for truth, justice, honesty, and the dignity of human life-including human rights-as well as for the value and dignity of citizenship.

This requires openness, political diversity, equality of status among national citizens, community members and officeholders, a free press committed to upholding the mandate of the 1945 Constitution, as well as the autonomy of institutes of higher learning and science.

In connection with this process of democratization, urgent priority must be given to the following areas:

\section{a. National institutions}

- End the present state-of-emergency-like conditions in the country by dismantling all institutions that do not conform to the 1945 Constitution.

- Promote greater openness in the activities of national institutions, including the Supreme Advisory Council and the Supervisory Council for State Finances.

- Release the judiciary from its subordinate position under the influence of the executive branch of government and restore the institutions of the judiciary to the status they should have under the Constitution.

- Promote an autonomous and independent party and community organization system 
- Hold a direct, open, free, just, and honest general election that preserves the secrecy of the ballot. Election results should be the one and only basis upon which positions of the People's Advisory and People's Legislative Councils are filled. Selection of Assembly candidates and the specific posts they fill should proceed with no interference from outside parties.

- Reform the general election system in order truly to reflect the sovereignty of the people.

- Uphold the freedom of assembly, organization, and oral as well as written expression.

- Make the positive aspects of the UN Declaration on Human Rights the underlying values that guide Indonesian law.

- Return the status and function of the Armed Forces to those specified by the 1945 Constitution.

- Release the country's police force from its present classification as a part of the Armed Forces.

- Require the bureacracy to carry out its role as service provider rather than wielder of power.

b. Presidency

- Unconditionally limit the period for which one person may hold office as president to a maximum of 2 terms in accordance with paragraph 7 of the 1945 Constitution. The present president's own period of office will end in 1993, at which time the present officeholder will no longer be an eligible candidate for re-election.

- The president should be nominated and elected by the People's Advisory Assembly.

- Determine that any presidential candidate be competent both to take oath as head of state for the Republic of Indonesia, and publicly to acknowledge that he/she is bound by the sovereignty of the people.

- Reaffirm the Indonesian President's accountability to the People's Advisory Assembly in line with the 1945 Constitution; require that the Indonesian President grant full authority to the People's Assembly for determining the Broad Guidelines for the Nation's Direction for the duration of his term.

- In connection with this, the function of the People's Advisory Assembly should be fully revived, by, among other things, holding parliamentary sessions more than once every five years.

c. Relationship between representative institutions and the government

- Increase the authority of the representative bodies of government, both on the central and provincial government levels, such that these assume a more decisive role than that of the executive branch without reducing the role of the presidential cabinet. In particular, a much stronger role for the People's Legislative Assembly must be secured in connection with budget issues.

- Supply the representative bodies of the government with professional support staff and reliable equipment in order to allow these to carry out their functions well.

- Secure the optimal functioning and use of the rights of representational bodies, including the right to question, the right to express an opinion, the right to poll, the right of interpellation, the right to make amendments, the right to take an initiative, as well as the right to formulate national budgets.

- Eliminate the right to recall members of the people's representative bodies.

d. Regional Autonomy

- Implement a realistic regional autonomy policy.

- Strike a genuine balance between provinces and the center in terms of finances. 


\section{e. Foreign Relations}

- Maintain a foreign policy that freely and actively works to achieve and keep world peace as would best serve the interests of our country.

- All violations of Indonesian sovereignty, like acts of piracy in Indonesian waters, must be stopped.

\section{Economy}

The government should pursue economic democracy in line with paragraph 33 of the 1945 Constitution, which directs the government to ensure just distribution of wealth, improve community awareness of issues of national economic development, and prevent business monopolies held by single persons or single groups. Economic actors in pursuit of business should be protected from unhealthy competition with each other. The value of the Rupiah should always be preserved and protected.

a. Cooperatives

- Guide cooperatives towards true independence and a primary position in the economy, such that the capacities of all citizens, even those at the poorest level, can be engaged in the national economy and in national development.

- Undertake efficient and effective measures in assigning different economic roles to cooperatives.

b. State-owned enterprises

- Rehabilitate state-owned enterprises as strategic instruments for implementing national economic policies and as effective guides for the wider citizenry in the economic sphere. This includes upholding the constitutional mandate regarding national economic principles. In assuming these functions as expected, state enterprises should be run according to modern principles of business management, with a degree of autonomy appropriate to their tasks.

- Establish state enterprises in those centers of economic activity that would fulfill the constitutional mandate with regards to establishing control over the country's mineral, water, and natural resources in the interest of ensuring the greatest prosperity possible for the people. In connection with this, state enterprises can be active in all areas of industry.

c. Private business

- Consolidating economic power in the hands of a few individuals and groups clearly violates the 1945 Constitution and should be resolved by law.

- Business activities not reserved for cooperatives and state enterprises may be assumed by private parties only if these do not result in monopolies or oligopolies, and only if they do not cause social gaps to be widened in the country.

- A private business should not be allowed to control an entire industry, from its upstream to its downstream stages.

d. Wages

- Realize real increases in the people's income from year to year.

- Establish a minimum wage in line with human needs.

- Set a maximum income limit through a tax system which thus prevents a sharp differential between the highest and lowest levels of income. 
e. Foreign economic relations

- Re-establish the function of foreign aid as an economic supplement without causing the country to be bound by its donors.

- Maintain a selection process with regard to foreign aid that does not undermine our national interests and status.

- Facilitate an optimal degree of technology, management skill, and shareholding transfer to indigenous Indonesian citizens.

- Involve the People's Legislative Assmbly in the process of evaluating foreign aid.

3. Society and Culture

- Promote a philosophy and attitude shaped by religious and cultural values affirming truth, justice, and honesty.

- Make the household the main pillar of the community, and uphold the primary role of mothers as educators.

- Promote democratic education, both formal and non-formal, that in turn promotes strength of character, intelligence, and skills among all students; pay proper attention to planning for holistic human resource development.

- Uphold the autonomy of institutes of higher education and science, including those devoted to research. Student organizations should be autonomous as well.

- Pursue technological development while tending to the needs of the labor force and to the protection of the environment.

- Promote art that cultivates creativity in line with religious and cultural values.

- Make publishing and the mass media (both printed and electronic), the means for sharpening the minds of the citizenry and for building their strength of character and morals. The products of the publishing field should be made affordable to the wider community.

4. Religion

All thoughts and actions, principles and measures assumed and undertaken in connection with the areas discussed above (politics, economy, and culture) should be pursued in keeping with religious values and teachings.

Jakarta, 22 August 1992

On behalf of the Conference,
A. Madjid
Deliar Noer
H.R. Dharsono 


\section{Document 3}

\section{FORUM FOR REALIZING TRUE SOVEREIGNTY OF THE PEOPLE (FRTSP) \\ Mailing Address: FORUM, P.O. Box 8101/JATPA.}

JAKARTA 13081

\section{Jakarta, 3 October 1991}

Re: $\quad$ Founding of the Forum for Realizing True Sovereignty of the People

1. President of the Republic of Indonesia

2. Coordinating Minister for Security Police of the Republic of Indonesia

3. Minister of Defense and Security of the Republic of Indonesia

4. Minister of Internal Affairs of the Republic of Indonesia

c.c.:

1. Leaders of the People's Advisory Council of the Republic of Indonesia

2. Leaders of the People's Legislative Council of the Republic of Indonesia

With all due respect,

We hereby announce that on August 22, 1991, the Forum for Realizing the True Sovereignty of the People was formally established. The founding principles of the Forum are clearly outlined in the Declaration Establishing the Forum for Realizing the True Sovereignty of the People and the attached supplement which we are enclosing with this letter.

Our basic aim in establishing the Forum for Realizing the True Sovereignty of the People is to strive for a spirit of renewal in the genuine and systematic implementation of Pancasila and the Constitution of 1945, without undermining their true and fitting continuity.

It seems that the convictions of this Forum are very much at one with those expressed by the President of the Republic of Indonesia in his National Address on 16 August 1991, where he stated: "We have also asserted that Pancasila is an open-minded ideology. This means that we ensure an ongoing process of renewal and regeneration that serves to refresh our understanding and perceptions."

It is by no means impossible that we will be able to realize the renewal envisioned by the government, even though we may sometimes encounter differences of opinion.

Did not the President himself firmly stress in the course of his national speech: "Differences of opinion are natural, healthy and legitimate"?

May our announcement receive all due attention. With this, we express our thanks.

Forum for Realizing the True Sovereignty of the People Forum Leaders, 


\section{Document 4}

\section{FORUM FOR REALIZING TRUE SOVEREIGNTY OF THE PEOPLE (FRTSP) \\ Mailing Address: FORUM, P.O. Box 8101/JATPA}

JAKARTA 13081

Jakarta, 17 October 1991

1. Leader of the People's Advisory Assembly

2. Leader of the People's Legislative Assembly

3. President of the Republic of Indonesia

in Jakarta

\section{MEMORANDUM I}

Re: General elections and violations of Pancasila and the Constitution of 1945

With all due respect,

We hereby present this memorandum regarding several violations of Pancasila and the Constitution of 1945 in the hope of securing the proper attention and response.

The violations of which we speak are as outlined below:

I. People's Advisory Assembly Decree No: VII/MPR/1978 and Interim People's Advisory Assembly Decree No: XI (1966)

Included in the preamble to the People's Advisory Assembly Decree No.: VII/MPR/1978 regarding General Elections is a resolution that holds as follows:

Noting: a. that the Republic of Indonesia is a State based on the Sovereignty of the People as specified in Pancasila and the Constitution of 1945.

b. that implementation of the principle of the People's Sovereignty necessitates the existence of Institutions of Deliberation and Popular Representation established by General Election;

c. that, for this reason, a People's Advisory Assembly is required to organize the General Elections and thus to put a democratic and constitutional way of life based on Pancasila and the Constitution of 1945 fully into practice.

Recalling: 1. Paragraph 1 Article (2) and paragraph 2 of the 1945 Constitution;

2. ....... and so on .....

The body of the above-mentioned Decree elaborates further:

\section{Paragraph 1:}

(1). General elections comprise the means for implementing the principle of People's Sovereignty based on Pancasila within the Republic of Indonesia. These are to be conducted directly, openly, freely, and according to secret ballot.

(2). General elections are to be executed by taking a general vote, in accordance with the principles of Pancasila Democracy

The People's Advisory Council Decree No. VII/MPR/1978 expressing the resolutions outlined above fundamentally, unequivocally and genuinely expresses and upholds that which is mandated by Pancasila and the 1945 Constitution. The issues raised above elaborate upon the principles of the Interim People's Advisory Council Decree No. XI/1966. The latter decree also mandated the prompt 
establishment of institutions of deliberation and popular representation in order to re-assert the genuine and systematic implementation of the 1945 Constitution.

\section{People's Legislative Assembly and the Executive Government Deviate from People's Advisory Council Decree VII/MPR 1978}

It has become evident that the following laws,

1. No.1 (1985) in connection with Law No. 15 (1969), in connection with Law No. 4 (1975); in connection with Law No. 2 (1980);

2. No. 2 (1985) in connection with Law No. 16 (1969), in connection with Law No. 5 (1975); as well as other legislation concerning the general elections and the composition and status of the national Institutions of Deliberation and Popular Representation

contain stipulations that are at odds with People's Advisory Council Decree No. VII/MPR/1978. This in turn clearly means that these ordinances also deviate from the principles of Pancasila and the Constitution of 1945.

One result of the passing of legislation that violates Pancasila and the 1945 Constitution in this way has been that general elections being executed in fact violate the very norms of People's Sovereignty that are upheld by Pancasila and the 1945 Constitution.

Following Law No. 1 (1985) concerning General Elections:

General Elections are to be executed in a fashion that:

-narrows the space for freedom to organize and assemble;

-curbs the freedom to express opinions and ideas;

-proceeds without autonomous and independent monitoring;

-proceeds without monitoring of party financing and election campaigning; and

-shackles and effectively squelches the freedom and independence of popular political parties to nominate their own candidate by requiring an official screening of all candidates' political affiliations.

Another result of this kind of legislation has been essentially to promote the emergence of Institutions of Deliberation and Popular Representation that assume a composition, status and function which fundamentally depart from the mandate of Pancasila and the Constitution of 1945, and in particular also from the People's Advisory Council Decree No. VII/MPR/1978.

The MPR-RI Decree upholds the principle that realizing the People's Sovereignty requires institutions of deliberation and popular representation that are established by general election.

In practice, however, positions within the present institutions of deliberation and popular representation of this country are filled both by election and by appointment. Indeed, the number of People's Advisory Assembly members who are appointed even exceeds the number of those who are elected. Clearly, this conflicts with Paragraph 1 article (2) of the 1945 Constitution.

\section{True renewal of the spirit of sovereignty must take place}

The situation described above must not be allowed to continue. We must have a true renewal of the spirit of sovereignty. This is especially true in light of the civilization based on the rule of law which underpins our society. We all know that we must uphold a rule of law that firmly establishes the following principle: any regulations or ordinances which conflict with or deviate from higher law must be declared "ILLEGITIMATE AND VOID BY LAW."

In a National speech given on 16 August 1991, the President clearly declared that we must all be willing to engage in ongoing adjustment and revival. Emphasizing this declaration, the President explained further:

"We have also already asserted that Pancasila is an open-minded ideology. This means that we will ensure an ongoing process of renewal that refreshes our ideas and perceptions."

It is also necessary for us to point out that, while receiving the participants of the 1990 Indonesian Army Seminar at the Presidential Palace in December of 1990, the President emphasized that: 
"the policies, strategies, and framework for carrying out the tasks of government must be modified from time to time, because the citizenry we serve and the world around us are changing constantly, while the government itself also changes and develops."

Continued the President:

"the policies, strategies, and overall framework that may have been appropriate for past decades will not be entirely appropriate for the future."

\section{APPEAL TO THE PEOPLE'S ADVISORY COUNCIL, THE PEOPLE'S LEGISLATIVE COUNCIL, AND THE GOVERNMENT}

In light of the points we have raised above, we urge the People's Advisory Assembly, the Peoples Legislative Assembly, and the Government to open their eyes and recognize the present situation. Urging resolute self-reflection, we call on them to undertake radical changes, and a complete purging of all regulations and ordinances that deviate from or conflict with Pancasila and the Constitution of 1945. In particular, we urge that priority be given to legislation that involves the following issues:

- Composition, status, authority, and function of the People's Advisory Assembly/People's Legislative Assembly/Provincial Legislative Assemblies.

- Status, authority, power, duties, responsibilities as well as duration of office of the President;

- Freedom to organize and assemble;

- Freedom of expression in oral, written, and other forms;

- General Elections

- Party System.

If we are truly committed to systematically and genuinely implementing the principles of Pancasila and the 1945 Constitution, these are the main problems that the PEOPLE'S ADVISORY ASSEMBLY, PEOPLE'S LEGISLATIVE ASSEMBLY, and the GOVERNMENT absolutely must address before holding the next general elections.

We are convinced that only if we work together to address the imbalances we have discussed here will we be able to secure improvements without inviting social upheaval.

The people will bestow their highest respect upon the People's Advisory Assembly, People's Legislative Assembly, and Government if these parties show themselves to be willing to make amends and engage in a total purging of all deviations from Pancasila and the 1945 Constitution.

However, if the People's Advisory Assembly, People's Legislative Assembly, and Government do not display any intention of correcting themselves, if they reject the process of cooperation, then we fear that sooner or later the people will draw their own conclusions, also in regards to the upcoming elections.

We are certain that the Government, the People's Advisory Assembly, and the People's Legislative Assembly are aware that the people already possess the necessary awareness and political maturity constitutionally to reject all measures or policies that stray from Pancasila and the 1945 Constitution. This has been proven by a number of incidents surrounding irregularities encountered in the election of village heads as well as by a number of demonstrations in which the people are challenging those measures that violate their rights.

Facing a situation like this, there is no other route for us to take but to join in the effort to give voice to the conscience of the people by defending their human rights and asserting the sovereignty that has been mandated by Pancasila and the Constitution of 1945.

May the issues raised in this correspondence secure your attention and understanding. With this we express our many thanks.

Forum for Realizing True Sovereignty of the People Forum Leaders, 


\section{Document 5}

\section{FORUM FOR REALIZING TRUE SOVEREIGNTY OF THE PEOPLE (FRTSP) Mailing Address: FORUM, P.O. Box 8101/JATPA}

JAKARTA 13081

Jakarta, 19 November 1991

Leader of the People's Legislative Assembly

Republic of Indonesia

Jakarta

Dear Sir,

We were shocked to read the announcement by the Army Central Information Office and the press release issued by the Armed Forces Command of the Republic of Indonesia regarding the incident in East Timor this past November 12. This announcement and press release were issued through various mass media channels in the capital.

We are very concerned about this incident first of all because it has up until now been our belief that our country is a peaceful and safe one. We are also concerned about the large number of casualties in the incident, including those who have been wounded and especially those who have been killed.

In our opinion, the incident clearly calls for the deployment of a fact-finding commission by the People's Legislative Assembly, whose duty among other things would be to visit the site of the incident to collect information openly from local civilian officials, local military officials, as well as the community. Members of this commission should be drawn from all party fractions. With this, we urge that:

- all parties seek objective explanation regarding the incident;

- the image of the People's Assembly as a representative body of the people be upheld;

- resolution of the incident be reached in a wider sense, namely in a way that allows integration of East Timor and the development of that province to proceed in a better way. In connection with this, government policies up until the present must be reviewed: Have these taken a sufficiently persuasive, democratic, pedagogical, and psychologically oriented approach? Or has the government emphasized only a security-oriented approach, overly focussed on developing physical aspects of the province and neglecting to cultivate a sense of peace and trust in the region?

In urging the formation of a People's Assembly commission we do not intend to deflect from the government's efforts to form a national investigating commission. Indeed it is our opinion that a People's Assembly commission can provide important input to the national investigators in the process of resolving this issue.

In the meantime, we also wish to observe that bringing those responsible for the incident to court in a way that resolves the incident in a lawful manner from the start, will very much help to boost the community's trust in the government. Resolution of this incident by means of the law will also help uphold the government's authority.

We very much hope the opinions raised in this letter receive your full attention. Thank you.

Forum for Realizing True Sovereignty of the People Forum Leaders:

cc: President of the Republic of Indonesia Minister of Defense and National Security, R.I.

Minister of Internal Affairs, R.I.

Armed Forces Command of the Republic of Indonesia

Governor of the Province of East Timor

Agents of the Press 


\title{
Document 6
}

\section{PEOPLE'S LEGISLATIVE ASSEMBLY OF THE REPUBLIC OF INDONESIA Jalan Jenderal Gatot Subroto-Jakarta 10270}

No: $\quad$ PW.00/5682/DPR RI 1991

Status: Important

Process: Immediately

Encl.: None

Re: Response to the Proposal to Form a Fact-Finding Commission on the Dili Incident

\author{
Jakarta, 17 December 1991 \\ Leaders of the Forum for Realizing True \\ Sovereignty of the People (FRTSP) \\ Jakarta
}

We have received your letter of November 19, 1991, addressed to the Leader of the People's Representative Assembly, and we wish to express our thanks.

In connection with the proposal you have raised in your correspondence concerning the deployment of a Fact-Finding Commission by the People's Assembly regarding the incident in Dili, East Timor, the Leadership of the Assembly is of the opinion that such a measure would be unnecessary. We have made this decision in light of the fact that a National Investigating Commission has already been formed which includes a representative from the Assembly among its members. It remains for us at this point simply to wait for the the commission to fulfill its duties. Results of the investigation will be made public. In the meantime, the People's Assembly itself has also held a special meeting with the Government in order to discuss this issue.

This correspondence is being sent to you for your information. We thank you for your attention to this matter.

$$
\begin{aligned}
& \text { Assembly Leader, } \\
& \text { M. Kharis Suhud }
\end{aligned}
$$

cc:

Secretary General of the People's Legislative Assembly

\section{Document 7}

\author{
FORUM FOR REALIZING TRUE SOVEREIGNTY OF THE PEOPLE (FRTSP) \\ Mailing Address: FORUM, P.O. Box 8101/JATPA \\ JAKARTA 13081
}

1. People's Advisory Assembly of the Republic of Indonesia

2. People's Legislative Assembly of the Republic of Indonesia

cc:

1. President of the Republic of Indonesia

2. Supreme Advisory Council of the Republic of Indonesia

3. Supreme Court of the Republic of Indonesia 


\section{MEMORANDUM II \\ FORUM FOR REALIZING TRUE SOVEREIGNTY OF THE PEOPLE}

Re: The East Timor incident as a standard for assessing Government policy in realizing peace and well-being

Respected Assembly Members,

With this correspondence we would like to express our opinions, views, and demands regarding the incident that took place in East Timor on November 12, 1991. We do this in the hopes of gaining the attention and understanding of the People's Advisory Assembly and the People's Legislative Assembly.

We are of the complete opinion that the East Timor incident is indeed an internal matter that must be resolved by us, the citizens of Indonesia alone. Nevertheless, this incident should not be viewed and handled as no more than a simple infraction of the law. Rather, this incident must also be understood for what it is: a measure of the success or failure, of the appropriateness or inappropriateness of the Government's and President's policies for establishing a true sense of peace and well-being in this our homeland.

As our starting point in this matter, we refer to the following, established constitutional principles:

1. The Preamble to the Constitution of 1945 establishes a mandate obligating the Government to protect the entire Indonesian citizenry and the entire Indonesian motherland.

2. Sentence 3, paragraph 2 of the Introduction to the General Overview of the Guidelines for State Policy for the Fifth Five-Year Plan states:

"Pursuit of the development process as a sincere expression of Pancasila principles means, in essence, a holistic development of the Indonesian people and of the Indonesian community in its entirety. From this perspective, the main aim of the next 25 years of our development process will be to bring into being an Indonesian people and Indonesian community steeped in an atmosphere of peace and inner well-being, rooted in a structure of civic and national life firmly based on the principles of Pancasila, and well established in a civic atmosphere that holds in supreme balance the relationship people have with each other, with their community, with the natural environment, and with God Almighty."

Given the existence of these constitutionally based principles, the People's Advisory Assembly and the People's Legislatiive Assembly must not avoid addressing the central problem at hand, namely that:

- The Constitution of 1945 and the Broad Guidelines of the Nation's Direction assign the Government the duty of protecting the people while creating an atmosphere of peace and inner well-being in our homeland.

In connection with these issues, we appeal to the People's Advisory Assembly, the People's Legislative Assembly, and the Government to focus their attention on the problem of establishing peace, calm, and a feeling of well-being in this country. In practice, up until now maintaining security has been the focus of attention, while the problem of achieving tranquillity has been largely ignored.

While sustaining security has always been singled out and emphasized as a primary concern, virtually no attention has been paid to sustaining tranquillity, and neither a passing thought has been given, nor passing gesture made to the question of well-being. And yet, as noted above, the Broad Guidelines for the Nation's Direction themselves have made creating a state of peace and true wellbeing the priority aim of the country's development.

In light of this, the exclusive attention being focussed on maintaining national security comprises a fatal mistake. This is a situation that requires total correction. 
An atmosphere of peace and true well-being (a structure of peace and well-being) is possible only if a sincere and honest effort to protect the people is made. Efforts to protect the people must be directed by wise policy. This noble effort must not be motivated by a lust for power. It must also not be linked with the abuse of power.

In practice, however, up until now, any efforts made to protect the people have centered on a security-oriented approach, resting on the sheer power of the Armed Forces.

The security-oriented apparatus has usually been very sensitive about any criticisms or proposed corrections. Those who do not follow orders are often considered to be lacking in proper respect for the Indonesian Armed Forces. Respect for the people is, however, never considered.

This "policy" can at best create only an apparent and superficial security, one that is not accompanied by peace and a sense of true well-being in our Homeland.

The bloody incidents that have taken place in Tanjung Priok, Lampung, Aceh, and most recently on a frightening scale in East Timor, are clear evidence of the failure to create a true and deep-seated peace in our country. Violent measures taken in the process of clearances of land, homes, and farm fieldsthe very source of people's livelihood; intimidating threats of violence brandished in front of demonstrations; arbitrary measures that continue at present-all of these are events that destroy hope of creating true peace in the life of the people.

Indeed, if we examine this matter more closely, like it or not we must admit that our country has yet to experience the true peace that can permeate the inner soul of the people. The people do not feel at peace to express their differences of opinion with the Government; indeed they are still surrounded by a sense of fear about criticizing the Government. The press itself, often said to be the King of the World, is not at peace to present a free public opinion, because it can, at any time, be closed down, razed to the ground essentially, without due process of law. The people are given no peace to organize amongst themselves in order to give orderly voice to their aspirations. Any sense of control people may have has been effectively squelched, because they lack the tranquillity needed to exercise it.

Drawing from what we have publicly presented above, we are of the opinion that the East Timor incident is only the tip of the iceberg. We feel that:

-The Government and President have failed in the duties assigned to them by the 1945 Constitution and the Broad Guidelines for the Nation's Direction, namely that they: ...... protect the people while establishing an atmosphere of peace and true and inner well-being in this our homeland.

We appeal to, indeed we urge and demand that the People's Advisory Assembly, which has the authority and the obligation always to monitor and control the President, and the People's Legislative Assembly, which has within its power always to monitor and control the President, quickly and decisively to address the problems and issues outlined above, in other words to address:

-the President's failure to fulfill the duties assigned to him by the 1945 Constitution and Broad Guidelines for the Nation's Direction.

At this time, it is both fitting and necessary that the People's Advisory Assembly and the People's Legislative Assembly compel the President of the Republic of Indonesia to assume responsibility for this failure.

In addition, we also demand that any government established in our Country be a government that is motivated by wise philosophy, and not a government driven by the lust for power and based on the abuse of power. In connection with this, the security-oriented approach must be replaced by an approach oriented towards peace and well-being.

Furthermore, it is our opinion that a restructuring of the Armed Forces must also take place in our country. We will present our concepts regarding this matter shortly. 
In short, with this correspondence we have presented our opinions and demands in connection with the East Timor incident. It is our great hope that the problems and issues presented here will receive the proper attention of the People's Advisory Assembly and the People's Legislative Assembly.

With this we express our many thanks.

Forum for Realizing True Sovereignty of the People Forum Leaders

Abdul Madjid

Deliar Noer

H.R. Dharsono

\section{Document 8}

Harian Terbit

Saturday, 11 January 1992

Deliar Noer:

"GOLPUT" REFLECTS LACK OF TRUST IN THE THREE PARTIES

One vocal figure, Prof. Dr. Deliar Noer, discusses the "golput" 2 phenomenon. This group of people, he suggests, will increase steadily in the course of the 1992 General Elections. One indicator of this is the increasing numbers of people taking part in demonstrations and the increasing numbers of disenchanted voters.

Current evidence also suggests a new phenomenon is emerging. Those engaging in demonstrations or other acts of protest are also threatening to join the ranks of the "golput." Deliar Noer sees this trend as a reflection of the lack of trust many citizens feel towards the three political organizations (Development Unity Party [PPP], Golkar, and the Indonesian Democratic Party [PDI]).

At the close of the symposium discussing the General Elections organized by the Forum for Realizing True Sovereignty of the People held at the residence of Ali Sadikan on Thursday evening, Deliar Noer, presently acting as Chairperson for the Forum, voiced some of his opinions to Abd. Ghofur of "Terbit."

A new phenomenon is emerging at present. Demonstrations are being held by certain community organizations that are being linked to threats of joining the ranks of the "Golput" in the General Elections later this year. How do you assess this situation?

The 1992 General Elections will be but a repeat of previous elections. Not the least bit of difference will be evident. The government has spoken about greater openness, yet we do not yet seem to be headed in that direction. Is it true that greater openness is occurring? The press itself probably knows more about this. Should the press begin to openly discuss the experiences of those who are disenchanted, it probably would quickly become subject to scrutiny, regardless of any new openness.

The General Elections will be conducted as before. What exactly do you mean by this?

Just to name one example, in the past election candidates had to undergo screening; today we have "litsus." 3 In the past, there were three contesting parties (PPP, Golkar, and the PDI), today there are

2[Indonesian acronym for "golongan putih" referring to those people whose ballots remain "white" or "blank," that is, those people who choose not to exercise their right to vote.]

${ }^{3}$ Editor's note: "Litsus" is a special screening procedure instituted by the Indonesian government and armed forces in 1990 to replace the old political screening process for those being considered for employment in the civil service, the military, and politically "sensitive" positions such as the press. Where the previous screening 
still the same three parties. How can we possibly seek new alternatives if we are not even allowed to discuss these issues?

Returning to the question of "golput," for a developed country voter abstention is not considered to be a problem. Yet in developing countries this is still turned into a measure of the People's participation in building democracy. What is your opinion?

In countries like Australia, citizens are even obligated to vote. If they do not, they are fined. By contrast, in countries like the US and in Europe, voting is not an obligation but simply a right. So, greater emphasis is placed on promoting awareness. Thus, if those choosing to vote equal $60 \%$ of the population, this is already considered quite good.

And what about Indonesia?

Well the problem is knowing what we should be emphasizing. The General Elections of 1955 laid greater emphasis on promoting awareness. While today, the level of awareness aimed at is more or less simply just to make things only appear lively.

What is your opinion regarding those demonstrations connected with golput's threats to boycott the elections?

These are emerging from a basic sense of dissatisfaction. People are demonstrating because they are dissatisfied; they are demonstrating because they do not feel what the government is doing is effecting any real change. Thus, their aspirations are not being adequately met, nor even being considered.

\section{Will this affect the 1992 General Elections?}

Yes, I believe so.

How will we be able to tell if this is affecting the actual election process?!

I don't know exactly if this will affect the election process. But I am certain that it will affect the number of persons taking part in the election.

Could this also mean that the socio-political organizations we have now are not functioning very well?

No, they are not functioning very well! These organizations are acting essentially as a kind of "supplement" to the political process. This is not the way the people who founded these organizations intended them to be. Those people did, you know, have certain ideals about civic life, about community life, about development.

What role will the Forum for Realizing True Sovereignty of the People play as witness to the 1992 celebration of democracy?

I myself do not regard the General Elections as a celebration of democracy. Celebration of democracy is really not an accurate label here. The elections demand a sense of responsibility from us. Talking about a celebration implies that all people have to do is join in, without taking things seriously. In a celebration people may merely be swept along in the current. By contrast, the kind of participation that we very much want is a process of realizing the true sovereignty of the people.

process had aimed at determining that those hired were "personally untainted" by any blood relationship to other persons known to have any association with Communist activity, the present "litsus" process now aims at determining that candidates for employment or office within the government are untainted by any influence by Communist or similar ideology. Present "litsus" guidelines also envision that this screening process be applied to a wider range of the citizenry, including those applying for employment or a position within the nongovernmental sector as well. 
There are some who feel that we do not need to establish any new parties, rather that it would be enough simply to realize the true function of the socio-political organizations (the political parties) that already exist. What is your opinion?

Why must we limit ourselves? You know this only limits the people's rights.

Can you explain this in more concrete terms?

If the number of people who will abstain from voting is increasing, then you know this means they do not believe in the three parties that do exist; these parties are not enabling them to give voice to their own aspirations and desires.

\section{Document 9}

\section{FORUM FOR REALIZING TRUE SOVEREIGNTY OF THE PEOPLE (FRTSP) Mailing Address: FORUM, P.O. Box 8101/JATPA}

JAKARTA 13081

Jakarta, 20 February 1992

1. People's Advisory Assembly of the Republic of Indonesia

2. People's Legislative Assembly of the Republic of Indonesia

cC:

1. President of the Republic of Indonesia

2. Supreme Advisory Council of the Republic of Indonesia

3. Attorney General of the Republic of Indonesia

4. Political Parties and Golongan Karya

5. Relevant community and people's organizations

MEMORANDUM III

FORUM FOR REALIZING TRUE SOVEREIGNTY OF THE PEOPLE

Re: -Military government

-Taxes and sovereignty of the people

-Economic democracy

Dear Assembly Members,

We hereby express our opinions, views, and demands regarding the issues specified above as outlined in the following pages:

MILITARY GOVERNMENT

If we consider the ordinances which presently apply in this country, it becomes impossible for us to avoid the observation that nothing other than a Military Government prevails in our Homeland today. 
The section on the Defense of National Security in the 1988 Broad Guidelines for the Nation's Direction [BGND] states the following:

In accordance with the Doctrine of the Defense of National Security, a system for maintaining total security among the people is to be established.

In the implementation of the above-mentioned doctrine, the Armed Forces of the Republic of Indonesia form the core of the system for Maintaining Total Security among the People.

The Armed Forces of the Republic of Indonesia constitute a Social Force in addition to its capacity as a Security Force.

Note: here we see that the Broad Guidelines refer to a doctrine, whose legal validity is lower than that of the Broad Guidelines themselves. This is an inexcusable mistake which should not be allowed to occur.

Item 10 of the sub-section "Defense and Security," section "Development Direction and Policy," of the 1988 Broad Guidelines states further:

The Armed Forces of the Republic of Indonesia fill a role as a force for the defense of national security and as a socio-political force.

In implementing its socio-political function, the development of the Armed Forces capacity will be geared towards:

- securing their ability to fill a role as stabilizer and dynamicist of national life,

- securing their ability to fill a role as active participant in national development

- strengthening the constitutional and democratic way of life and upholding the law in fortifying national defense.

In addition, paragraph 28, article (2) in Law No. 20/1982 regarding Main Points for the Defense of National Security includes the following specification:

The Armed Forces is to be actively involved in increasing and fortifying national security by the following measures:

- participation in the decision-making process on national and government issues.

- developing Pancasila democracy and a constitutional way of life based on the 1945 Constitution through all forms of national development enterprises and activities

Note:

Italics reflects our emphasis.

From the points of the 1988 Broad Guidelines for the Nation's Direction and of Law No. 20/1982 outlined above, we may conclude that:

- The Indonesian Armed Forces constitute the CORE of the System for the Defense of Total Security among the People;

-The participation of the Armed Forces in making national and government decisions (i.e., in active policy-making) has been presented as an ABSOLUTE CONDITION necessary for the Armed Forces to be successful in increasing and fortifying national defense.

-For their role in national development, in strengthening a constitutional way of life, democracy, and rule of law, and in fortifying national defense, the Armed Forces are being oriented towards a role as ST ABILIZER AND DYNAMICIST OF NATIONAL LIFE.

In addition to these points, in our country we have an institution called the Council for the Defense of National Security, which analyzes, plans, even directs and controls politics in a real way and with a firm grip. Finally, the 75-100 seats within the People's Advisory and People's Legislative Assemblies which are reserved for representatives of the Armed Forces clearly place the Armed Forces in a political position with far more clout than the position of ordinary citizens. 
From what we have described above, it is clear that the Armed Forces (as a fully equipped state tool, well organized, fully armed, and soundly state-funded) are being promoted, upheld, handled, and operationalized COMPLETELY as a POLITICAL PARTY-plus (to be distinguished from a normal political party); as such, the Armed Forces have been placed in a DOMINANT POSITION AND ROLE in society. We can, in short, say that the Armed Forces occupy a place and role as central axis in our civic and national life.

A government that underpins and upholds the Armed Forces in the position described above is in essence none other than a Military Government.

\section{TAXES AND THE SOVEREIGNTY OF THE PEOPLE}

The talks presented at the Plenary Session of the People's Legislative Assembly on 6 January 1992, have provided us with a clear picture that taxes drawn from the people have been made a central source of national income for 1992-1993. In connection with this, the government has even announced that it will firmly pursue the collection of taxes, applying sanctions regardless of who the delinquent taxpayer may be.

This kind of policy will be regarded as fair from the point of view of humanity and justice as long as there is some kind of compensation for the burden that will be placed on the people. A fair return for this burden would include:

- Replacement of the Military Government with a Government based on the sovereignty of the people.

Such an exchange would not only be fair, it would be an unequivocal display of respect and honor for the sacrifices of the people.

In connection with this, we demand that the People's Advisory Assembly of the Republic of Indonesia holds a Special Session to cancel the points made by the 1988 Broad Guidelines for the Direction of the Nation which we outlined above, and to replace these with new guidelines. These should:

- Place the Armed Forces in a position and role that adhere to the mandate specified by the 1945 Constitution, and

- Uphold the inviolable sovereignty of the people.

This would also require that any other Decisions and Decrees issued by the People's Assembly which stray from Pancasila and the 1945 Constitution be promptly corrected.

Should technical or financial constraints make it difficult for the People's Advisory Assembly to hold a Special Session, it would be most appropriate for the task of discussing these issues then to fall on the Assembly Working Group. As far as we know, the People's Assembly has never once held a conference to discuss the possibility of such a Special Session or Working Group. A conference should be called immediately to discuss these issues. In addition to the above demands, we also demand that the People's Legislative Assembly hold a session to discuss the points raised, and that they in turn urge the People's Advisory Assembly to call a Special Session.

\section{ECONOMIC DEMOCRACY}

In the opening speech to the People's Legislative Assembly session of 6 January 1992, the Assembly Leader stated that:

- As a reflection of the spirit and intent of the directive specified in paragraph 33 of the 1945 Constitution, cooperatives, state enterprises, and private enterprises should be given equal opportunity to grow and develop.

It is our opinion that the main principle of this paragraph, namely:

- to provide cooperatives, and private and state-owned enterprises with an equal opportunity to grow and prosper, 
will create competition for useful opportunities between the three forms of enterprise specified. In the economic situation in which we presently find ourselves here in our homeland, we can already predict that cooperatives will be left far behind, while private enterprise, particularly the conglomerate groups within this sector, will grow rapidly, leaving others with little chance of catching up. The ideals behind upholding cooperatives as a central pillar of our economy as mandated by paragraph 33 of the 1945 Constitution will be lost in the process.

We hereby appeal to His Eminence, the Leader of the People's Legislative Assembly, to withdraw those statements in his opening speech which referred to this issue.

As regards the People's Legislative Assembly as a whole, we demand that the Assembly urge the Assembly Leader to make the necessary corrections in the speech he presented at the Session opening on 6 January 1992.

If the principles expressed in the speech have also helped shape the national budget planning process, then the People's Assembly must make some radical changes in the 1992-1993 budget which was presented to the Government by the Assembly on January 6, 1992.

In conclusion, we very much hope that the People's Legislative Assembly will give special attention to the opinion expressed by a number of economists and political specialists, that:

- economic democracy can only be fostered under the protection of a government which itself is a democratic one.

It is for this reason that we must make realizing true sovereignty of the people our national priority.

May the issues raised in this correspondence receive the attention and reception they require. With this we express our many thanks.

Forum for Realizing the True Sovereignty of the People Forum Leaders,

Abdul Majid

Deliar Noer

H.R. Dharsono

\section{Document 10}

FORUM FOR REALIZING TRUE SOVEREIGNTY OF THE PEOPLE (FRTSP)

Mailing Address: FORUM P.O. Box 8101/JATPA

JAKARTA 13081

Jakarta, 20 Feburary 1992

His Eminence the Leader of the People's Legislative Assembly of the Republic of Indonesia Jakarta

cc:

1. President of the Republic of Indonesia

2. People's Legislative Assembly of the Republic of Indonesia

3. All Fractions of the People's Legislative and People's Advisory Assemblies, Republic of Indonesia

4. Leaders of the Supreme Advisory Council 
5. Attorney General of the Republic of Indonesia

6. Golongan Karya, Development Unity Party, Indonesian Democracy Party

7. Other relevant parties

\author{
MEMORANDUM IV \\ FORUM FOR REALIZING TRUE SOVEREIGNTY OF THE PEOPLE \\ Re: $\quad$ - Fact-Finding Commission to East Timor \\ - Address given by the Leader of the People's \\ Legislative Assembly \\ - Discussion of the National Budget Plan
}

Dear Sir,

We begin this memorandum first by expressing our appreciation and many thanks for your willingness to consider and respond to our letter of 19 November 1991 in the letter of 17 December 1991 which we received from the People's Assembly (Correspondence No. PW.00/5682/DPR RI/1991).

In the present correspondence, we would like to raise the following issues:

\title{
POSITION AND RESPONSIBILITIES OF THE FACT-FINDING COMMISSION
}

We can understand that the Leaders of the People's Legislative Assembly feel it is unnecessary to form its own Fact-Finding commission, given that a National Investigating Commission has already been established, whose members include a representative from People's Assembly itself.

Yet we would like to point out to you that our correspondence of 19 November 1991 proposes that an Assembly Fact-Finding Commission be assigned the tasks of collecting information from local civilian government and military officials as well as the wider community regarding the East Timor incident. With this, it was our hope that:

- all parties receive objective information about the said incident;

- the image of the People's Legislative Assembly as a representative body of the people would be boosted;

- the Assembly would be able to suggest a resolution of the incident in a wider sense, namely one that would improve the process of integrating and developing East Timor province. In connection with this point, it is necessary to consider whether the government's measures up until now have been more of a persuasive, democratic, pedagogical, and psychological approach, or whether these measures have been more of a security approach, focussed exclusively on the physical aspects of development and insufficiently so on cultivating a sense of peace and trust.

We can accept the decision by the leadership of the People's Legislative Assembly not to form its own Fact-Finding Mission as long as the following conditions apply:

1. The People's Assembly member who has been chosen for membership in the National Investigating Commission (NIC) is a representative spokesperson for the Assembly;

2. The People's Assembly member thus placed on the NIC has been assigned the responsibility for completing those tasks which we have specified above, in addition to completing his/her tasks as a formal NIC member;

3. This Assembly member is accountable to the People's Assembly for carrying out the tasks assigned him/her. 
If the current situation is as we specify in the three points above, we very much hope to obtain information on the results of the existing Commission's work.

\section{ADDRESS GIVEN BY THE PEOPLE'S LEGISLATIVE ASSEMBLY LEADER}

In the address opening the People's Legislative Assembly Session on 6 January 1992, the Assembly Leader stated:

- "The Assembly has already asserted that the East Timor incident did not reflect the policies of the Indonesian Government as based on Pancasila."

At first glance and in a purely legal sense, we can indeed approve of the Assembly's statement. Yet, let us not by no means ignore that:

- The People's Legislative Assembly is a Political Institution,

- The Assembly Leader's address was a political address, and

- The East Timor incident was an entirely political incident and not simply a purely legal one.

From a political perspective, the assertion the Assembly Leader makes carries the following implications:

- Because the East Timor incident did not reflect the policies of the Indonesian Government, the incident was not the government's responsibility; thus, the government should not be held responsible and should not be made to assume responsibility.

We believe it is quite clear that the Assembly Leader's assertion as noted above cannot be considered an appropriate or fitting one; indeed, it constitutes a serious blunder that degrades the status of the People's Legislative Assembly.

Yet it is an assertion that indeed has been made by the Assembly; we therefore strongly urge the Assembly to withdraw the statement immediately, in order to preserve its status and avoid tarnishing its name.

\section{DISCUSSION OF THE NATIONAL BUDGET PLAN}

The address given by the People's Assembly Leader closing the Assembly Session on 6 January 1992 gave us the impression that the Assembly would discuss the National Budget Plan (NBP) only in quantitative terms.

We all know that the National Budget Plan is not simply a matter of figuring income and expenditures in money terms terms only. Rather, it must also engender active formulation of Government policy on managing the country and guiding its citizens in all areas of life.

We very much hope that the People's Legislative Assembly will fundamentally regard and discuss the 1992-1993 NBP in the way we have outlined above.

It would certainly not be too much for us to ask the Assembly to direct its attention to the problem of developing, strengthening, and preserving the appreciation and perception of nationalism and democracy, given that these issues have been badly neglected in the 1988 Broad Guidelines for the Nation's Direction. This neglect is made evident by the fact that appreciation for and understanding of nationalism and democracy were not identified as the basis, foundation, basic capital, as well as dominant factors behind national development. Yet, as the third and fourth sentences of the Preamble to the 1945 Constitution show us, nationalism and democracy occupy a central and fundamental place in our country.

We hope that the issues raised in this correspondence receive the attention and consideration they require. For this, we would like to express our many thanks.

\section{FORUM FOR REALIZING TRUE SOVEREIGNTY OF THE PEOPLE Forum Leaders,}




\section{Document 11}

\section{FORUM FOR REALIZING TRUE SOVEREIGNTY OF THE PEOPLE (FRTSP) \\ Mailing Address: FORUM P.O. Box 8101/JATPA}

JAKARTA 13081

No.: $\quad$ 199202/FPKR/1992

Re.: Abuse of power and measures to avoid it

Leaders of the People's Legislative Assembly and

People's Advisory Assembly of the Republic of Indonesia

Jakarta

Respected Assembly Members,

As put forward in the Preamble to the 1945 Constitution, the ideals of independence which we hold deeply stress values of "humanism and justice," "justice and prosperity," "bringing to life a liberated nationalism," "promoting general prosperity, strengthening civic life," "establishing the sovereignty of the people," "One Almighty Divinity," and "social justice." In addition, the government is obligated to "protect all Indonesian citizens and the whole of the Indonesian Motherland..."

It was in the context of these principles that, at the beginning of his current term in office, the President of the Republic of Indonesia took an oath in front of all members of the People's Advisory Assembly and 176 million Indonesian citizens, in accordance with paragraph 9 of the 1945

Constitution. This oath began with the words "By God" and continued with the promise "to fulfill my duties ... in the best and most just manner possible," by "adhering closely to the Constitution and executing all laws and regulations truly, and serving the homeland loyally." Breaking this oath would incur the wrath and curse of God. May this be a tragedy that we avoid.

These points make clear that it is the President, not his ministers, not the governor, or any other official, who carries the responsibility for all government policies and their implementation. This is even more so the case if we consider the key ingredients of the New Order legacy, specifically in the economic sphere, which were put forward by President Suharto in front of a full session of the People's Legislative Assembly; these included both those proposing a "total correction" of the leadership provided by President Sukarno, as well as those referring to "New Order resolve." These points asserted that during the period of Guided Democracy, "the wealth of the nation was used for personal gain" and "the licensing system (in the guided economy) .... favored only a small segment of people, who were close to those in power."

In the following paragraphs, we present several examples of the abuse of power (and also of violations of the oath discussed above) and possible means to avoid them for the good of all our citizens.

\section{Examples of the abuse of power:}

1. In connection with the case of Bank Duta, first publicized in 1990, we have noted that:

- a donation of U.S. $\$ 400$ million was made by President Suharto to the bank;

- three foundations connected with the Bank were headed by President Suharto

These kinds of donations raise questions about where the President was able to procure such large amounts of money. And was this money taxed properly?

Other questions include: Can the head of state of the Republic of Indonesia head a foundation? To whom would he be accountable as head of the foundation? Can his position as foundation director be separated from his position as head of state? Won't this foundation tend to engage in business without paying taxes? 
2. The President has allowed his sons and daughter, close relatives as well as other businesspersons to develop a capitalist economy. Because of this, monopolies have emerged in a number of business sectors. All of these developments conflict with paragraph 33 of the 1945 Constitution.

3. Recent cases including BPPC [Clove trade monopoly], the West Kalimantan orange trade, and the collection of TV fees through the company PT Mekatama Raya, all involve the President's sons, daughter, and other relatives, such that the attitude of the President himself is put into question.

4. In 1986, when the Indonesia Plaza was being built, the President granted dispensation to PT Bimantara Eko Santoso (headed by one of the President's sons) allowing the company to postpone payment on state credit used to buy luxury items. Thus has evidence of the abuse of power by the President emerged. (See also "Empire of the Sons and Daughter," in Time, Asia Pacific edition, 3 February 1992, for more details.)

5. These examples comprise only a small portion of what could be added to this list of abuses.

\section{The Meaning of Development}

There is not one person among all Indonesians who would not approve of the kind of economic development intended in paragraph 33 of the 1945 Constitution. Development should not be a tool for legitimizing power that is shrouded in myth; it should also not imply economic development only for officials and their families and a small segment of the people concentrated in conglomerates and well connected with power elites. For development itself is paid for by the sweat of the people in the form of taxes, by the country's natural wealth, and by millions of dollars in foreign loans which then become a debt carried by all Indonesians. Therefore, development that is marked by nepotism, capitalism, and conglomerate-driven monopolies represents a contradiction: "developing people's prosperity on the one hand, chewing away at it on the other."

This disease must be stopped quickly before the virus spreads and attacks the central nervous system of the people's economy. First priority should be given to eliminating the primary source of life for this disease, namely the the kind of abuse of power to which Lord Acton referred in his observation: "power tends to corrupt, absolute power corrupts absolutely." Ibnu Khaldun suggests that the longer a person is in a position of power, the easier it is to succumb precisely to this tendency.

\section{FINDING A WAY OUT}

These issues make it clear that there is a great need for the People's Legislative Assembly to make serious effort to find both a way out of the current situation as well as the means for future prevention. More specifically, such effort should include:

1. forming an investigating team to review current cases of the abuse of power, a few of which have been described above.

2. forming an investigating team that monitors the wealth of state officials and their close relatives, before and after they assume office.

3. monitoring and putting a check on the flight of capital from the country to protect the interests of the nation.

4. preparing legislation that would specify the rights, power, and duties of high-ranking state officials, including the President; in addition, preparing legislation on the affairs of the central government as a whole which would give the People's Legislative Assembly greater opportunity and room for carrying out its duties. In this way, the rights and status of the people will be increased.

The points above imply certain consequences, namely that anyone known to be abusing their position of power (which in turn implies engaging in corrupt behavior) has no right to become a candidate for President. Also, the number of terms in office must be limited.

Thus are the views the Forum for Realizing True Sovereignty of the People (FRTSP) has to offer on the abuse of power and the means to prevent it, both now as well as in the future. 
May the leaders and members of the People's Legislative Assembly and the People's Advisory Assembly have the moral courage to say what is right is right and what is wrong is wrong. Maintaining an attitude that is anything less than frank will only obscure the problem, making the possibility for change little but a dream.

FORUM FOR REALIZING TRUE SOVEREIGNTY OF THE PEOPLE Forum Leaders,

Abdul Madjid

Deliar Noer

H.R. Dharsono

cc:

1. President of the Republic of Indonesia

2. Vice President of the Republic of Indonesia

3. Head of the Supreme Court of the Republic of Indonesia

4. Leaders of the Supreme Advisory Council

5. Attorney General of the Republic of Indonesia

6. Head of the Investigating Agency for State Finances, Republic of Indonesia

7. All Fractions of the Peoples Legislative and People's Advisory Assemblies, Republic of Indonesia

8. Leaders of Political Parties, Golkar, Community Organizations

9. Mass media

\title{
Document 12
}

\author{
FORUM FOR REALIZING TRUE SOVEREIGNTY OF THE PEOPLE (FRTSP) \\ Mailing Address: FORUM P.O. Box 8101/JATPA
}

JAKARTA 13081

\section{STATEMENT OF THE FRTSP REGARDING THE 1992 GENERAL ELECTIONS}

I. With special reference to:

A. Main points on Realizing True Sovereignty of the People

\section{Politics}

"While maintaining our belief in God and the people's right to rule, the process of democratization must be based on a deep appreciation for truth, justice, honesty, the value of human life including human rights, as well as for the value and dignity of being a national citizen."

In the context of this democratization process, urgent priority must be given to several areas, which include:

- Ending the present state-of-emergency-like conditions by dismantling those institutions which are not in accordance with the 1945 Constitution.

- Holding General Elections that are direct, general, free, fair, honest, and based on secret ballot, the results of which will comprise the only basis upon which positions of the People's Legislative and People's Advisory Assemblies are filled. Selection of candidates for these representative bodies and the positions they fill within them must be free from intervention by any external party. 
B. Memorandum No. I of the FRTSP regarding GENERAL ELECTIONS AND VIOLATIONS OF PANCASILA AND THE 1945 CONSTITUTION, dated 17 October 1991, was sent to 1) Respected Leaders of the People's Advisory Assembly of the Republic of Indonesia, 2) Respected Leaders of the People's Legislative Assembly of the Republic of Indonesia, and 3) the President of the Republic of Indonesia.

Core points :

a. Following the People's Advisory Assembly Decree No.: VII/MPR/1978 mandating that the sovereignty of the people be realized, we may assert the necessity of People's

Deliberating/Representative Institutions established by general election. Yet, several laws issued thus far, including:

a.1. Law No. 1 (1985), in conjunction with Law No. 15 (1969), in conjunction with Law No. 4 (1975) in conjunction with Law No. 2 (1980), and

a.2. Law No. 2 (1985) in conjunction with with Law No. 16 (1969) in conjunction with Law No. 5 (1975),

referring to General Elections as well as the role of current deliberating/representative institutions,

apparently institute resolutions that depart from the People's Advisory Assembly Decree No. VII/MPR/1978. By the same token, this clearly means that these decisions violate Pancasila and the 1945 Constitution as well.

b. All regulations and other legislation that conflict with or depart from higher laws and legislation are invalid and void under the law, and must be declared invalid and void under the law.

c. In light of these violations of the constitution, the FRTSP strongly feels it is necessary to engage in a process of purification and renewal.

d. To ensure this purification and renewal process takes place, FRTSP appeals to the People's Advisory Assembly, the People's Legislative Assembly, and the Government to open their eyes and boldly acknowledge the present situation, engage in critical self-appraisal, and promptly make the necessary CHANGES in and TOTAL PURIFICATION/PURGING of those laws which currently depart from or conflict with Pancasila and the 1945 Constitution.

C. A number of political experts and prominent statesmen have expressed the opinion that not voting does not conflict with existing laws and and does not incur liability for legal sanctions.

\section{CHOOSING NOT TO VOTE:}

- Comprises an open, firm, and bold political commitment not to participate, involve oneself, or simply follow along in a process that fundamentally disables DEMOCRACY. This means a refusal to accept the violations of Pancasila and the 1945 Constitution committed by both those to whom the sovereignty of the people has been entrusted, as well as the government and the People's Legislative Assembly, in the form of a number of laws which these parties have passed and executed, in particular within the field of politics.

- Comprises a choice made by a large part of the people whose rights have been downtrodden.

- Comprises a strong demand for more genuine efforts to carry out a process of renewal and democratization.

\section{POSITION TAKEN BY CURRENT POWERHOLDERS :}

Up through the present, the People's Advisory Assembly, the President, and the People's Legislative Assembly, have tended only to ignore all demands for genuine efforts to realize true sovereignty of the people, as mandated by Pancasila and the 1945 Constitution, forcing all such demands to continue and presenting the risk of eventual social turmoil. 
III. POSITION TAKEN BY THE FRTSP :

Following the points raised above, the FRTSP:

1. HAS TAKEN THE POSITION NOT TO PARTICIPATE IN THE 1992 GENERAL ELECTION

2. FEELS IT IS THE DUTY OF ALL THOSE WHO SUPPORT DEMOCRACY AND THE SOVEREIGNTY OF THE PEOPLE TO INCREASE THE NUMBERS OF THOSE WHO CHOOSE NOT TO VOTE

3. WILL MAKE EVERY EFFORT TO CANCEL ALL LAWS WHICH CONFLICT WITH PANCASILA AND THE 1945 CONSTITUTION

4. FEELS IT IS THE DUTY OF THE ARMED FORCES NOT TO VOTE IN ORDER NOT TO BLOCK THE CONSTITUTIONAL PROCESS OF RENEWAL AND DEMOCRATIZATION IN ALL AREAS OF LIFE.

IV. CONCLUSION

We present this POSITION STATEMENT OF THE FRTSP to the highest institutions of the state, other important state institutions, all MASS COMMUNICATION MEDIA, community organizations, nongovernmental organizations, political organizations, and other relevant parties.

Jakarta, 2 May, 1992

FORUM FOR REALIZING TRUE SOVEREIGNTY OF THE PEOPLE (FRTSP)

Forum Leaders,

Abdul Madjid

Deliar Noer

H.R. Dharsono 